\title{
COUNTING AND CONTEMPORARY GOVERNANCE: INTRODUCTION TO THE SpeCial ISSUE
}

Michael HaAN

\section{INTRODUCTION}

In many ways, the Census of Canada barely touches the lives of Canadians. It happens once every five years, requires only a few minutes to complete, and then nothing is heard from Statistics Canada, the agency responsible for administering the quincennial headcount, for nearly a year. As results begin to trickle out, only the smallest segments of society consult the information, and it is not always clear what they do with their newfound knowledge. So inconspicuous is the census that many Canadians would not even notice if Statistics Canada cancelled it altogether. ${ }^{1}$

As true as the above may be, the census is hardly invisible. It forms the backbone for nearly all government planning, from taxation to transportation infrastructure development. Almost all transfers of people, funds, and resources within and across levels of government are informed by the census. It is not an exaggeration to say that the census shapes the material and social reality of life in Canada, much as it does in other countries. That is why, for example, cities and states line up south of the border to sue the US Census Bureau after every decennial headcount, because that is the battleground for Congress seats, federal transfers, business rankings, livability assessments, and just about anything else that involves the distribution of resources.

Although we don't typically see such open conflict around the census in Canada, there does tend to be some post-enumeration grumbling here as well. In Alberta, for example, at what was nearly the height of the most recent oil boom, Statistics Canada had to make a post-census

1. In fact, in a discussion with some of my colleagues, I discovered that each of us had encountered at least one person in our travels who believed that the census actually had been cancelled. 
trek to the Regional Municipality of Wood Buffalo to address concerns about undercounting for 2006 (they subsequently agreed that their initial estimates were off by quite a margin). More recently, as I write this introduction, the town of Ramea, Newfoundland, is in the process of disputing what it saw as a significant undercount in the 2011 enumeration. There, Statcan counted 148 people, well below the numbers anticipated locally, and the 547 counted in 2006. Ramea's mayor Lloyd Rossiter assured residents that "[w]e'll be going to those people and saying, 'your information is incorrect." "2 Not exactly a US-style throw-down, but significant nonetheless.

Without a doubt, however, the biggest census-related controversy in recent Canadian history has been the Conservative government's 2010 decision to replace the mandatory long-form questionnaire with a nearly identical, voluntary, one. Detractors of almost every political stripe condemned the move as an egregious violation of a basic principle of good governance. In the days and weeks that followed, cosmopolitan Canada stood almost entirely united in its opposition to the move. Academics, charities, nongovernmental organizations, religious leaders, and just about everyone else seemed to agree that halting the collection of long-form census data, which began in 1971, was a bad idea. Without the long-form, how will we learn about ourselves? We won't be able to, many concluded, meaning we should anticipate less effective governments, and governance, in the future.

As severe as this reaction was, ${ }^{3}$ most of it focused on how devastating the data gap would be for Canada. Much less attention has been paid to the implications of a conscious decision to cancel Canada's primary information source for changes to the mechanics of government. What implications does cancelling the long-form census have for the neverending negotiation of the social contract between the government and its people? What does it tell us about how our government wants to govern?

These questions form the focus of this special issue of the Canadian Journal of Sociology. The cancellation of the 2011 long-form census creates space for sociological reflection on the interplay between population data collection and the politics of numbers in Canada's political ecumene. The four articles herein discuss the significance of the census, its consequences for understanding society, and what replacing the longform version with the National Household Survey implies about the innards of governance.

2. As cited in the Gulf News, available http://www.gulfnews.ca/News/2012-02-13/article-2893830/Rose-Blanche,-Ramea-dispute-census-numbers/1

3. According to one count, 370 organizations representing the whole spectrum of the Canadian population expressed their displeasure at the decision (Sheikh 2011). 
You will notice that this special issue does not identify whether cancelling the long-form census was "good" or "bad" — although several of the authors no doubt have opinions on this - but it instead looks at how the political landscape is shifting beneath our feet, and how this can be seen in a decision like the one made about the 2011 long-form census. The 2011 long-form census debacle should therefore be treated as a casualty, rather than a cause, of a new mode of governance in Canada. The articles in this issue of the Canadian Journal of Sociology begin to articulate the contours of this "new governance" model.

The intention of this special issue is to also demonstrate that there is no consensus on what this new governance looks like. Does the Canadian government no longer need or want detailed population information to form an effective government? Is it finding the information it needs elsewhere? Are Foucauldian biopolitics (1978) no longer a valid epistemological lens for understanding the governance strategies of incumbents? Has Ian Hacking's (1982) "avalanche of printed numbers" finally come to rest after nearly 200 years?

To provide some context for the four entries, below I outline the parameters of the census debate in 2010-2011, followed by a brief introduction of the papers in this special issue.

\section{Background to the 2011 Census Controversy}

Countries tinker with their data collection strategies all the time. Australia, the United States, and the United Kingdom are making, or are about to make, significant changes to how they collect information about the people in their jurisdiction. So, at first glance, many may have thought that Canada was just keeping up with the Joneses of data collection.

It quickly became evident, however, that the changes here were different from those of other countries. First, it was motivated by a desire to increase or restore individual liberty, not improve the quality of the data or the efficiency of the collection process. In presenting and defending the move, Industry Minister Tony Clement described the long-form census as "a terrible degradation of the social contract between the governors and the governed" (Hansard Parliamentary Papers, September 28, 2010), implying that the cost of knowing the information now exceeded its benefits. Furthermore, the Harper government claimed that: a) Statistics Canada had given them advice that a voluntary survey can produce results that are as good as a mandatory long-form census; and, b) that

4. Several otherwise worthy submissions had to be rejected because they focused on the deleterious effects of cancelling the long-form census. 
it, and its Chief Statistician fully supported the decision. Munir Sheikh resigned in protest, as he felt he could not misrepresent the implications of replacing a mandatory survey with a voluntary one.

Another indication that what was happening in Canada was different was the cloak of secrecy beneath which it proceeded. The Harper government, more or less, made the decision behind closed doors, without talking to any stakeholders about how this might affect them. Even within Statistics Canada, the move seemed to shock many, suggesting that there was little advance notice of the move within the Agency. In other countries, by way of contrast, affected groups are usually consulted before major changes are made to how data are collected. The absence of stakeholder engagement in a participatory democracy suggests that majority rule and the wisdom of the crowd was not a factor in the decision.

The final reason Canada's census change is different from other countries is how resolute the Conservative government was once the decision was made public. It didn't seem to matter how many people spoke out against the Harper government. From chief statistician to chief cook and bottlewasher, Stephen Harper's inner circle was not the least bit rankled by the pleas of those who rely on the rich data collected with the long-form census.

\section{The Census as Ontological Engine}

So, if everyone outside top Conservatives thought that cancelling the 2011 long-form census was a bad idea, why did it happen? Was it simply to restore individual liberty, to free Canadians from the invasive tactics of previous governments? Much like Pierre Trudeau wanted to get the state out of the bedrooms of Canadians, is Stephen Harper eager to get the state out of the lives of Canadians altogether? Although this is certainly possible, there are several competing alternatives, which I list briefly below.

Since enumerations have the power to support or refute entire government agendas, perhaps there was a concern about the accumulation of contradictory evidence. As Gandhi demonstrated nearly 100 years ago by endorsing the 1921 Census of India while adhering to his broader anticooperation principles against the British Empire, ${ }^{5}$ information from enumeration is mobilized by not only incumbent governments but also by groups that seek to delegitimize ruling powers.

5. One now-famous example of Gandhi's use of census data demonstrated the prevalence of child marriage (the 1921 census revealed over 600 brides that were less than one year old), eventually leading to the Child Marriage Restraint Act of 1929. 
As another example of how censuses can unseat governments, in December of 1800 British Prime Minister William Pitt's government passed "An Act for taking an Account of the Population of Great Britain, and of the Increase or Diminution thereof," setting in motion one of the first censuses in the western world. Pitt was motivated in part by the fear that Thomas Malthus's predictions about population outstripping resources would soon ring true, particularly as the war with Napoleon wore on; he wanted to be sure that internal collapse was not imminent. Pitt believed that only a full headcount could settle the score, and on March 10, 1801, 8.9 million individuals were counted in England, Scotland, and Wales on his watch. The headcount, which cost the people of England, Scotland, and Wales a handsome sum, did nothing to settle the debate over the existence of overpopulation in Great Britain, ${ }^{6}$ and helped Pitt lose the election later that year (he was re-elected in 1804).

Another possibility would include the delegitimation of the census as a nodal point for generating reality, or "making up people" as Hacking (2006) describes it. Headcounting undergirds identity formation by streamrolling diversity and organizing populations into comparable, identifiable, categories. Turning to an example from 19th century India, early colonial censuses transformed caste from regional tropes of differentiation into a fairly coherent national hierarchy (Walby and Haan 2012). By 1901, to avoid what British colonial officials considered to be confusion amongst Indians around what was and was not a legitimate caste, enumerators were given registries to follow, and were told to fit people in to existing categories. This virtually ensured harmonization, and as India began its call for independence, census data gave great weight to claims that the country was a distinct, independent, and naturally ordered, entity.

More recently in Canada, the mobilization of Caribbean communities in the 1980 s to be recognized as more than simply "Caribbean" or "West Indian" began with the census. It resulted in the acceptance of Jamaican in 1986 and Barbadian and Guyanese in 1991 as legitimate categories for the ethnicity variable. The degree of mobilization within the gay and lesbian community to identify as a same-sex household in 2001 was not only noteworthy, but one of the first official counts of same-sex relationships in the western world. Less seriously, even the Church of Jedi (of Star Wars fame) tried its best in 2001 to become a recognized religion, ${ }^{7}$ but, unlike the other examples mentioned above, Statcan nixed

6. The 1801 Census instead invigorated the overpopulation debate, and perhaps the most colorful detractor was William Cobbett, who in 1822 wrote about overpopulation: "I do not believe one word of what is said about the increase of the population.... [A] man that can suck that in will believe, literally believe, that the moon is made of green cheese."

7. http://www.ctv.ca/CTVNews/TopStories/20030513/census jedi 030513/ 
the idea for fear of confidentiality breach. The Church, and its roughly 20,000 adherents, never fully recovered.

Examples like these form the fodder for scholars like Bruce Curtis (2000) to conclude that censuses are made, not taken. Although the census is rarely identified as anything more than an instrument for eliciting facts about the enumerated, it also helps create and maintain the reality it represents. We can only speculate on how widespread the notion of a "visible minority" would be in the absence of the census. Perhaps this lack of control of an ontological engine was simply too much for our government to handle.

\section{The Census Debacle of 2010-2011 and Counting and CONTEMPORARY GOVERNANCE}

The four articles in this special issue advance the discussion introduced above. In the first article, James Cosgrave, Patricia Cormack, and Lynda Harling Stalker interpret the cancellation of the long-form census as a product of the renegotiation of the relationship between citizens and their state. They draw parallels between the unlikely topic of state monopolized gambling and the census. The authors illustrate how a well-designed theoretical framework allows for connections between seemingly unrelated areas.

Next, Susan McDaniel and Heidi MacDonald look at the quest for self-knowledge through most of history, and how the cancellation of the long-form in 2011 can be considered a halting of this quest. A government has traditionally wanted more, not less, information about its people, but here we have an instance of a government saying and doing the opposite. It seems as though the principle established by Prime Minister Pitt over 200 years ago is no longer relevant. McDaniel and MacDonald do not attempt to discern why the decision was made, but they conclude their interesting article by suggesting that the decision may stem from a desire within the annals of power to control the various arms of government. Maybe it was not so much about the census as it was preventing the provision of information to individuals (many of them civil servants) to present the government in an unflattering way.

William Ramp and Trevor Harrison situate the decision to cancel the long-form census, and the actions of the Conservative government more generally, as capitalizing on a growing appeal to libertarian populism, which in its purest form can be characterized as a return to government by "normal people" instead of elites and special interest groups. For normal people (which presumably most people would identify as), the 
long-form census was heavy-handed and elitist. Ramp and Harrison are careful to point out that Harperian libertarian populism does not necessarily describe the incumbents very well, but that it instead captures the gestures and statements that are made, even when they contradict what is actually happening. If true, the genius of the strategy is that every rebuttal or condemnation, whether it comes from an academic, NGO, or special interest group, indirectly supports the claim that the information was solely of interest or use to the elite.

Philosopher Michael Yeo closes the volume by reminding us that a normative relationship between science and politics has always existed. Many academic disciplines, such as ethics, philosophy of science, and science studies, have long concluded that "value-free science," even as an ideal is highly contentious, suggesting that people should not be surprised to see values enter into decisions such as the one to cancel the long-form census. Furthermore, Yeo argues that it is not only science that should be protected from politics, but also politics from science. Policy decisions are value decisions, and part of that process concerns the use of evidence.

What each of these articles has in common is an investigation of what changing the way data are collected in Canada suggests for contemporary governance. Some argue that things haven't really changed that much, whereas others see the shift as seismic. We hope you find that this special issue provides important insights on this emerging discussion.

\section{REFERENCES}

Curtis, Bruce. 2000. The Politics of Population. Toronto: University of Toronto Press.

Foucault, Michel. 1978. The History of Sexuality: The Birth of the Prison. Harmondsworth: Penguin.

Hacking, Ian. 1982. Biopower and the avalanche of printed numbers. Humanities in Society 5:279-295. 2006. Making up people. London Review of Books 28(6):23-26.

Sheikh, Munir. 2011. Good data and intelligent government. Pp. 305-336 in New Directions for Intelligent Government in Canada. Ottawa: Centre for the Study of Living Standards.

Walby, Kevin, and Michael Haan. 2012. Caste confusion: The epistemological problems of census enumeration in colonial India, 1871-1921. Social History/Histoire Sociale Forthcoming. 
230 (c) Canadian Journal of Sociology/Cahiers Canadiens de sociologie 37(3) 2012 